\title{
In which hospital departments may sexually transmitted diseases be seen? The views of 56 medical students
}

\author{
ANNETTE GOULDEN AND J. EARLE \\ From James Pringle House, Middlesex Hospital, London
}

SUMMARY Fifty-six medical students were asked to list the hospital departments where sexually transmitted diseases (STDs) might be seen and to name the conditions that might occur. The students mentioned 37 departments altogether. Forty-seven students listed six or more departments and 43 described 11 or more conditions that might be seen. The departments mentioned were placed in ranking order. Over half the students stated that patients with STDs might present in departments of dermatology, neurology, gynaecology, ophthalmology, general medicine, urology, and rheumatology. Writing the lists did not encroach on the time available for clinical teaching and it helped students to visualise the ways and places in which STDs may present. This form of teaching could be used in other branches of medicine.

\section{Introduction}

Many factors may be involved in determining whether a patient vith a sexually transmitted disease (STD) attends a general practitioner or a hospital department. A survey of 251 cases of primary and secondary syphilis who attended James Pringle House (JPH) between 1973 and 1975 showed that $22(8.8 \%)$ had previously attended a general practitioner before being referred directly to JPH. Five patients $(2 \%)$ had attended other doctors concerned with primary care. Twenty patients $(8.0 \%)$ had attended other hospital departments before their attendance at JPH and another 35 of 136 patients with secondary syphilis $(25.7 \%)$ had attended a dermatologist before coming to JPH (Earle, 1977 unpublished observation).

It is important that medical students should understand that patients with sexually transmitted disease may present in departments other than a department of venereology.

At the Middlesex Hospital, students are systematically taught about STDs in the Department of Venereology and Genitourinary Medicine at JPH. They are taught by lectures and discussions, by microbiological and serological demonstrations, by discussion with those concerned in tracing the sexual contacts of patients, and by observing the

Address for reprints: Dr J. V. Earle, Hailey Cottage, Hailey Lane, Hertford SG13 7NY.

Received for publication 21 December 1976 doctors at work in the clinics. The clinical aspects of the subject are taught in a manner similar to other branches of medicine, except that only one student attends with each doctor. STDs are also sometimes discussed in other departments.

We are involved in the clinical teaching. While ensuring that all are taught the basic principles, we attempt to make the discussion appropriate to individuals. We teach some who have had few formal lectures and others who have nearly completed the course of instruction.

The students are allotted individual times to attend the clinic and were not consciously selected for this survey.

\section{Method}

We asked the students their age and if they had developed a firm interest in a career in any particular branch of medicine or were still open-minded.

We reminded them that they would see STDs at JPH and we asked them to make a list of departments where they might see STDs and to describe the conditions that might occur.

\section{Results}

We taught 56 students during this survey: 42 men and 14 women. Their ages ranged from 20 to 27 years. Fifty were born in the UK and the others came from Arabia, Canada, Cyprus, India, and Malaya. One of the Arabs was visiting England in his elective year. 
We did not impose a time limit, but noted that the task was usually completed in between 5 and 10 minutes.

The number of departments named is shown in Table 1. The number of conditions that might be seen is shown in Table 2.

Three students did not mention any department, and three only named departments but did not mention a disease. Altogether 37 departments were mentioned. The ranking order is shown in Table 3 .

The ranking order of conditions named is shown in Table 4.

Table 1 The number of departments named by the students

\begin{tabular}{llllll}
\hline & \multicolumn{7}{c}{ Departments } \\
\cline { 2 - 6 } \cline { 2 - 6 } & 0 & $1-5$ & $6-10$ & $11-15$ & $16-20$ \\
\hline No. of students & 3 & 6 & 29 & 16 & 2 \\
\hline
\end{tabular}

Table 2 The number of conditions caused by STDs listed by the students

\begin{tabular}{llllllllll}
\hline \multicolumn{1}{c}{ Conditions } \\
\cline { 2 - 8 } & 0 & $1-5$ & $6-10$ & $11-15$ & $16-20$ & $21-25$ & $26-30$ & $31+$ \\
\hline No. of students & 3 & 1 & 9 & 20 & 12 & 4 & 6 & 1 \\
\hline
\end{tabular}

\section{Discussion}

This work did not encroach on the time available for clinical teaching. We could see whether or not the student understood the ways in which STD could present. The students were helped to visualise the alternative presentations of STD which added inierest to the clinical teaching. The idea of acquainting students with the position of one specialty in relation to other specialties has already been described in connection with radiology (Sinclair, 1968), and could be used in other branches of medicine.

Forty-seven $(84 \%)$ students could name more than six departments where they might see STDs and $43(77 \%)$ could describe 11 or more conditions caused by STD.

Eight students noted a department that nobody else had mentioned and five others gave a department or source of referral listed by only one other.

Two students who hope to become surgeons wrote lists tha: showed their interest was almost entirely surgical. Neither had realised that his approach was extremely selective until this was pointed out.

In the course of training, students pass from one department to another and do not always appreciate the relationships that exist between departments.
Table 3 The ranking order of departments listed by the students

\begin{tabular}{|c|c|}
\hline Department & $\begin{array}{l}\text { No. of students listing } \\
\text { department }\end{array}$ \\
\hline Dermatology & 45 \\
\hline Neurology & 41 \\
\hline Gynaecology & 39 \\
\hline Ophthalmology & 31 \\
\hline General medicine & 30 \\
\hline Urology & 30 \\
\hline Rheumatology & 29 \\
\hline Paediatrics & 28 \\
\hline General surgery & 27 \\
\hline Psychiatry & 24 \\
\hline ENT surgery & 23 \\
\hline Obstetrics & 22 \\
\hline Orthopaedics & 19 \\
\hline Cardiology & 18 \\
\hline Infections or communicable disease & 9 \\
\hline General practice & 8 \\
\hline Gastroenterology & 7 \\
\hline Accident or casualty & 5 \\
\hline Family planning & 5 \\
\hline Geriatrics & 5 \\
\hline Rectal surgery & 5 \\
\hline Dental surgery & 4 \\
\hline Infertility clinic & 3 \\
\hline Plastic surgery & 3 \\
\hline Antenatal clinic & 2 \\
\hline Pathology & 2 \\
\hline Radiology & 2 \\
\hline Tropical diseases & 2 \\
\hline Vascular surgery & 2 \\
\hline Chest medicine & 1 \\
\hline Community medicine & 1 \\
\hline Forensic medicine & 1 \\
\hline Neurosurgery & 1 \\
\hline Respiratory medicine & 1 \\
\hline School medical officer & 1 \\
\hline Services medicine & 1 \\
\hline Social services & 1 \\
\hline
\end{tabular}

Table 4 The 10 conditions most commonly named by the students

\begin{tabular}{ll}
\hline Condition & No. of students \\
\hline Neurosyphilis (all forms) & 41 \\
Secondary syphilitic rashes & 37 \\
Cardiovascular syphilis (all forms) & 31 \\
Congenital syphilis & 28 \\
Ophthalmia neonatorum & 24 \\
Reiter's disease & 21 \\
Salpingitis & 20 \\
Vaginal discharges (all causes) & 20 \\
Genital warts & 17 \\
Hepatitis & 14 \\
\hline
\end{tabular}

On discussing the completed lists, it appeared that the task had made the students think about these relationships and see that clinical problems can overlap departmental boundaries.

The authors thank Dr R. D. Catterall for his help in the preparation of this paper.

Reference

Sinclair, D. J. (1968). Radiology and the Edinburgh medical student. British Journal of Medical Education, 2, 293-296. 